\title{
ワタアブラムシの主寄主植物の記録ならびに 中間寄主植物への飛来について1
}

\author{
稲 泉 三 丸 \\ 宇都宮大学農学部応用昆虫学教室
}

（1969年10月 9 日受領）

Primary Host Plants for Aphis gossypii Glover, and its Landing on Secondary Host Plants. Mitsumaru Inaizumi (Laboratory of Entomology, Faculty of Agriculture, Utsunomiya University, Utsunomiya) Jap. J. appl. Ent. Zool. 14: 29-38 (1970)

Aphis gossypii Glover is a serious pest of the potato, many vegetables and flowers, and also an important vector of many plant viruses in Japan. The hibernating methods of this aphid has two forms, one of which is the fertilized eggs on the bud of primary host plants, and the other is the adults and nymphs of viviparous females on secondary host plants which survive winter. In this paper, the author has attempted to make clear the names of the host plant species for the hibernation of $A$. gossypii, in order to know the time of appearance of alate viviparous females on such plants in spring and the time at which alate viviparous females come flying on secondary host plants. In the past, Clerodendron trichotomum THunB., Callicarpa japonica ThunB., and Hibiscus syriacus L. were known in Japan as the winter hosts for A. gossypii, but the results of artificial transfer in early spring, of alate viviparous females which grow on these plants to secondary host plants, and morphological studies showed that aphids found on the plants mentioned above, excepting $H$. syriacus L., are not $A$. gossypii, that is, those found on $C$. trichotomum T. were Aphis clerodendri MAtsumura and those on $C$. japonica $\mathrm{T}$. were Aphis sp. The author adds three plants, namely Celastrus orbiculaturs ThunB., Rhamnus japonica MAxim., and Rubia cordifolia L. var. mungista Mig. as new primary host plants for $A$. gossypii in addition to $H$. syriacus L. The author also found that Veronica persica PoIR, $V$. didyma Tenore var. lilacina Yamazaki, V. arvensis L., Capsella bursa-pastoris Medicus, Althaea rosea Cav., Chrysanthemum morifolium RAMAT. var. sinense MAKino, Fragaria chiloensis Duch. var. ananassa Bailey, Plantago asiatica L., and Symphytum officinale L. may be considered as plants for the hibernation of the viviparous female. Alate viviparous females were found to emerge late in April on these plants for hibernation and during the first part of May on the plants for hibernation of the egg. By early or about the middle of May, alate viviparous females take off from the overwintered host plants and settle on Solanum tuberosum L., Cayratia japonica Gagn., Chaenomeles lagenaria Koidzumi, C. japonica Lindl., Vicia sativa L., Galinsoga parviflora CAv., and Chrysanthemum leucanthemum L., etc. Alate viviparous females' reproduction on these plants constitutes the major source for secondary colonization. The progenies in June, come flying to Solanum melongena L., Cucumis sativus L., Cucubita pepo L., Lagenaria leucantha RusBy var. depressa MAkino, Citrullus battich Fonskíl, and Colocasia antiquorum Schotr, etc. As for the source of colonization of $A$. gossypii found on $S$. tuberosum L., aphids found on $V$. persica Poir, $V$. didyma Tenore var. lilacina YAmazaki, $V$. arvensis L., and $H$. syriacus $\mathrm{L}$., etc. are the most possible ones.

$$
\text { 緒言 }
$$

ワタアブラムシ Aphis gossypii Glover は, 多くの 農園芸作物に寄生して，直接的な被害を与える一方，各
種の植物ウイルス病の媒介虫としても知られる重要な害 虫である。

本虫の生活環については，日本では柴田（1955）の研 究があり, 秋季に有性世代が出現して，ムクゲ，クサギ

1 本研究の一部は昭和 41 年度文部省科学研究費によった。 
飞産卵し, 翌春, 受精卵が卯化して幹母となり，その子 孫から生交れた有翅胎生雌虫（以下「有翅虫」と書く） は, ヤブガラシ, ナス科, ウリ科などの中間寄主植物に 移って胎生世代をくりかえすと述べている。

ワタアブラムシの分布は全世界におよんでいるが，日 本以外の国々に淤发活環は，日本と同様に有性世代 の出現する完全生活環を営なむ場合もあり，また，台湾 (TAKahashi, 1932), エジプト,イスラエル (BodenHEIMER and SWIRSKI, 1957), 北米, ヨーロッパ (EASTOP，1958），オーストラリア（EASTOP，1966）では有 性世代の出現しない不完全生活環を営んでいる。

冬寄主植物については, 日本では柴田のほか森津 （1948）の報告があり，ムクゲ，クサギ，ムラサキシキ ブをあげている。外国では，汇口（1937）は，朝鮮に おいてザクロ，ムクゲ，フヨウに産畉すると述べ，柴田 (1955) は, 満州ではムクゲ, オオバコに産卵すると述 ベている。また，KRING（1959）は二ューヘブン(北米) に打いては, ムクグ, Catalpa bignonioides WaLT. (ア メリカキササゲ，ノウゼンカズラ科）に産卵することを 報告している。

わが国のワタアブラムシは上述の上らに，卵越冬する ことはょく知られているが，胎生雌越冬することや，卵 および胎生雌越冬の寄主植物については, よくわかって いないようである。

筆者は，1964〜1969年にか汁て，ワタアブラムシの主 および中間寄主植物を調查しあわせて越冬寄主植物と それらからの春の中間寄主植物への移動の経路などにつ いて観察し，若干の知見を得たので報告する。

本文にはいるにあたり，ご指導いただいた当教室の田 中正教授，アブラムシを同定下さった Dr. V. F. EAsTOP，宗林正人博士，および植物名をご教示下さった本 学の森谷憲助教授に厚くお礼申し上げる。

調查方法および結果

\section{I. 越冬寄主植物}

秋から初冬にかけて野外飞おいて種々の植物を観察 し，ワタアブラムシの産卵雌虫および卵の有無を調査し た。また, 冬季間, 緑色を保つ植物上に本種の胎生個体 が見られるかどらかについて調査した。この調査によっ て発見した卵㧍よび胎生個体を春まで野外で観察し，餒 化する時期と，有翅虫の発生する時期を調査した。ま

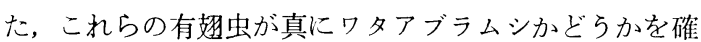
認するため, 春もっとも早く本種の寄生を受けるジャガ イモに移し，幼虫を産むかどうか，またさらに，その幼
虫が成虫まで育つかどらかを見た。

飼育の方法は，寄主植物上で越冬した即および胎生雌 から生まれた有翅虫をその植物体についたまま実験室に 持ち帰り，あらかじめ，直径 $21 \mathrm{~cm}$ の素焼製植木鉢に植 えておいた草丈約 $10 \mathrm{~cm}$ のジャガイモ葉に面相用の小筆 で10頭ずつ移した。鉢には他からの有翅虫の飛来と，他 への逃亡を防ぐため第 1 図のようなガラス鐘をかぶせ

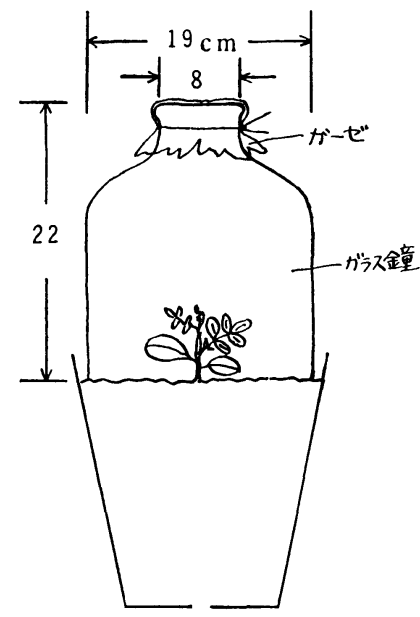

第 1 困 ワタアブラムシの接種試験に用いた飼育器具。

た。有翅虫の移動（接種）には羽化後数時間を経過した 個体を用い，24時間後および48時間後に幼虫を産んだか ぞうかを調査した。幼虫を産まないものについては，さ らに羽化後24時間, 48時間, 70時間腰高シャーレ(高さ $8 \mathrm{~cm}$, 直径 $9 \mathrm{~cm}$ ）内に絶食状態で保った個体を用いて 接種した。このようにして接種試験を行なった結果，幼 虫を産まないものについてはワタアブラムシとしては認 めがたいと判定し，接種に用いた有翅虫を分類学者へ同 定依頼した。また，幼虫を産んだものについては，その 後数世代の飼育を続けられるかどうかを見，さらに生育 した個体の色彩および形態とを検討してワタアブラムシ であることを確かめ，その有翅虫の寄生していた植物を 寄主植物として認定した。

なお，アブラムシの同定は筆者が BODENHEIMER and SWirski (1957), Eastop (1958), Takahashi (1966) によって行ない，疑問のあるものについては分類学者へ 同定を依頼した。また，ここではアブラムシの形態的， 分類学的な点についての詳しい記述は省略する。

\section{1. 卵越冬寄主植物（主寄主植物）}

\section{a) クサギ}

從来, クサギ Clerodendron trichotomum THUNB。は林 
津 (1948)，柴田（1955）により，わが国のワタアブラ ムシの卵越冬（主）寄主として知られていた。

本植物では10月20日過ぎに交尾が行なわれ，11月初め に太い幹や小枝に産卵するのが見られる。この卵はその まま越冬し, 翌年 4 月末に捊化し, 幹母となる。幹母の 子孫は $2 \sim 3$ 世代をくりかえして数量的に增加し，5月 末から 6 月初めに春季移住する有翅虫が出現する。この 頃になると, 寄生を受けた本植物の若い葉は捲縮する。 有翅虫は 1 葉に数 10 頭にものぼるが，6月中旬までには 大部分飛散する。ごく一部の有翅虫は本植物上にとどま り, 無翅胎生雌虫（以下「無翅虫」と書く）を産み, 秋 季まで数世代をくりかえす。

本植物上で羽化した有翅虫のジャガイモへの接種は 6 月初め行なったが, 羽化後数時間, 24時間, 48時間, 70時 間いずれの区でも，接種後 $24 〜 48$ 時間以内にジャガイモ 葉を離れてガラス鐘の内壁にとまって歩行したり，飛し ょうして,ついには死亡した。同じょうな方法で無翅の 幹母の子孫や無翅虫を用いて $6 \sim 8$ 月に数回, ワタアブ ラムシの中間寄主植物であるジャガイモ, サトイモ, キ ュウリ，カボチャに接種してみたが，いずれの場合にも 幼虫を産むことなく，48時間後に逃亡または死亡した。 また, 逆に, ジャガイモに寄生しているワタアブラムシ を,クサギの葉に接種してみたところ, 幼虫を産さ場合 もあったが，24時間後に死亡し，生育しなかった。

この結果から，筆者はクサギに寄生するアブラムシは ワタアブラムシとは異なる別の種類と考え, British Museum の Dr. V. F. EASTOP に同定を依頼したところ, クサギアブラムシ2 Aphis clerodendri Matsumura, 1917 であることがわかった。よって，クサギにはワタアブラ ムシは寄生せず, 卵越冬もしないといら結着になったの である。たしかに両種は形態的に非常によく似ているた め混同されていたものと思われる。

\section{b) ムラサキシキブ}

ムラサキシキブ Callicarpa japonica THunB. は森津 (1948）によって, ワタアブラムシの主寄主として報告 されたものである。

本植物上においては，10月末に小枝の先端に多数の卵 が産下され，そのまま冬を越し，翌年の 4 月10日前後に 卯孚化する。4月中旬に幹母となり，その後その子孫は 2 〜 3 世代をくりかえして 5 月10日前後に有翅虫が羽化す る。有翅虫の見られるのは 5 月いっぱいで, 羽化した個 体から順次飛散する。一部の有翅虫はとのまま本植物上
に幼虫を産み、秋季まで世代をくりかえす。 接種試験は 5 月初めジャガイモのほか, タチアオイ, ミカンを用いて行なったが，いずれも幼虫を産まないで 48時間後に植物体を離れて死亡した。

本植物に寄生するアブラムシは小形で，角状管がみじ かく，体色も褐色〜灰色で白粉を装うなどワタアブラム シの形態と相違する点があるので, 同標本を皇学館大学 の宗林正人博士に送付したところ, ワタアブラムシとは 異なる他のAphis の1種といらご教示を受けた。種名 についてはさらに検討中である。

\section{c) ムクゲ}

ムクゲ Hibiscus syriacus L. は花を観賞する目的で多 くの人家の庭先きに植えられ，さらに生垣としても多く 植えられている。古来, わが国のほか, 満州, 朝鮮, 北 米などから本虫の主寄主植物として知られていた。

本植物上では11月初, 中旬に盛んに交尾が行なわれ, 落葉したあとの芽の付近に褐色の卵を産む。この卵はあ とで黒っぽくなる（第 2 圀の 1 ）。翌年 4 月10日前後に 芽が開くと同時に卯孚化し, 非常に小さい葉の基部で幹母 になり,その後 $2 \sim 3$ 世代をくりかえして個体数を増 す。 5 月10日前後に有翅虫の幼虫が多数出現し, 展開し た葉の裏で羽化する。この有翅虫の個体数は 1 葉あたり 30〜 50頭となり, おびただしい数にのぼる。本植物上に 有翅虫の見られるのは約 1 か月間で，6月20日前後には ほとんど姿を消す。一部の有翅虫は先端の若い葉に幼虫 を産み, 秋季まで胎生世代をくりかえすが，あまり多く ない。

ジャガイモへの接種を行なったところ, 羽化数時間, 24時間いずれの個体でもよく幼虫を産んで増殖をつづ け，6〜7 日後には黄色の成虫になり, さらに $4 \sim 5$ 世 代の飼育が可能であった。羽化後の有翅虫を絶食状態で 腰高シャーレ内に入れておくと，70時間後にはそのガラ ス壁にも多数の幼虫を産み，また，その中にムクゲの葉 を入れてやると, その葉にもよく幼虫を産むことがわか った。そのほか, 羽化後 24 時間経った有翅虫をタチアオ イに接種したところ, よく幼虫を産み, そこで育った成 虫は黄色になった。

この結果から，ムクゲに寄生するアブラムシはワタア ブラムシであることがわかり，また，本植物の有翅虫は ジャガイモをはじめ多くの中間寄主植物に飛来するもの と推定できる。ムクゲの卵から生をれた有翅虫をジャガ イモに接種した場合，そこで育った成虫の体色は黄色で 


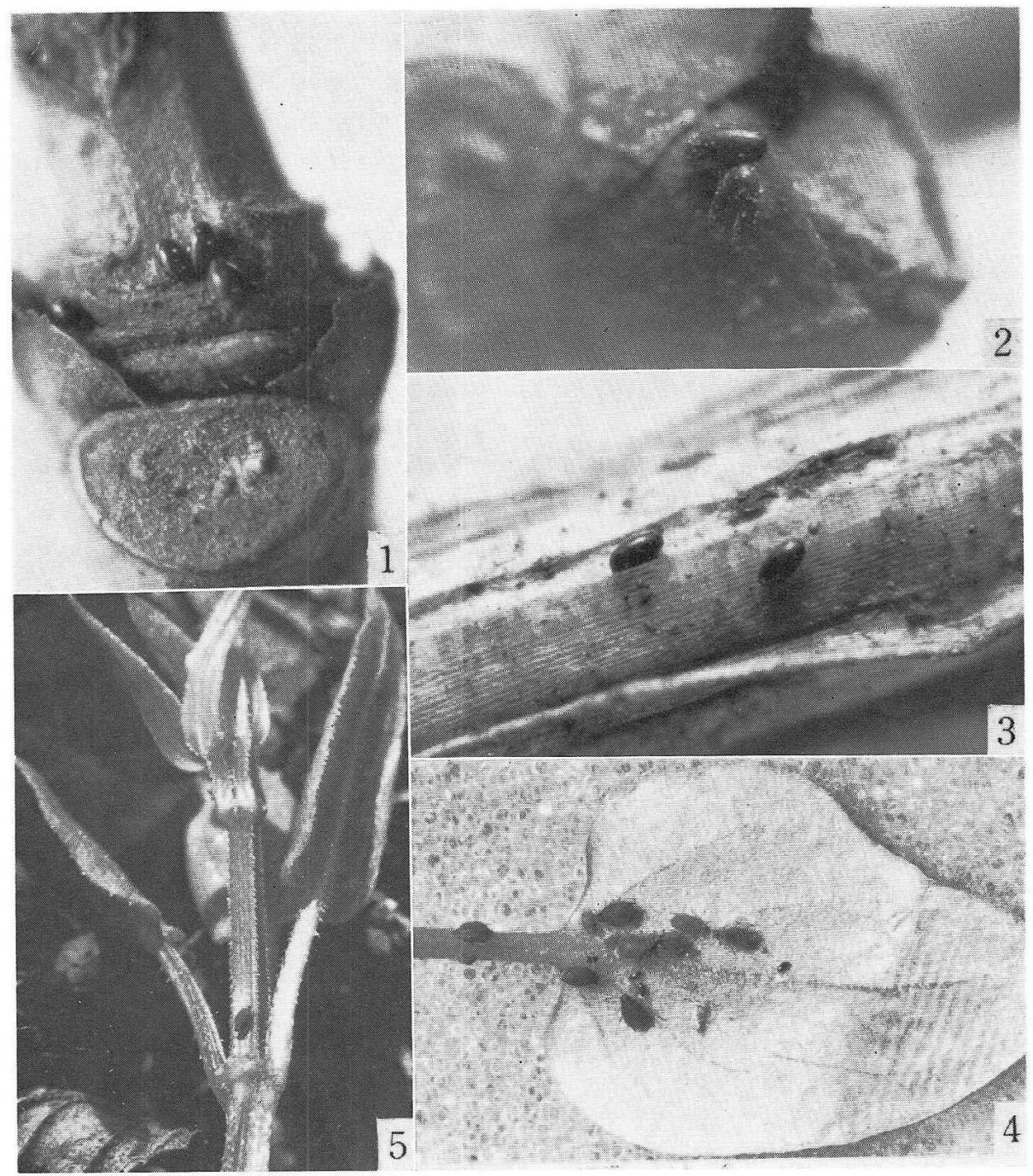

第2図 主寄主植物上のワタアブラムシ (1)。1.ムクゲの小枝上に産みつけられた卵。2.ッルゥメモ ドキの芽に産みつけられた卵。3.アカネの枯れた茎に産みつけられた卵。4．枯れかけたアカネの葉上で産卵 する産卵蜌虫。5，地中から芽を出したばかりのアカネに乗り移った孵化幼虫（幹母の幼虫）。

小型の個休になるが，実際野外のジャガイモにも，これ と同様な色彩，形態をした個体が多く奇生している。

\section{d) アカネ}

アカネ Rubia cordifolia L. var. mungista MiQ. は多 年性の蔓植物で水田や畑地周辺に普通に見られる雑草で ある。瞢は $2 \mathrm{~m}$ 以上にも達し, 畑地周辺の生垣や樹木, 雑草にまきついていることが多い。本植物は進士(1941) によりワタアブラムシの寄主植物となることが報告され ている。また，Börner and HEINZE (1957) は同属の Rubia sp. が本種の寄主植物となることを述べている
がまだ主奇主植物としては知られていなかった。 筆者は1967年11月初め, 宇都宮大学農学部戋場緣の三 ズキの生垣に卷きついている地上約 $1 \mathrm{~m} の$ 本植物の半ば 枯れかけた茎や葉より多数の本種の産卵雌虫之, 産下さ れたばかりの褐色の卵を発見した（第 2 図の $3 ， 4$ ）。 その後, 栃木県内各地の本植物を調査したところ, 多く の枯れた本植物の茥や葉より卵を見つけることがでを た。本植物体の地上部は冬季には枯死し, 卵を付けた茎 や葉は次第に風雨に打たれて折れ地上に落ちる。このよ うな状態で卵は地上で冬を越したが，4 月初め，㥀物体 
が地中から芽を出吉と同時に卵は卯化し，その幼虫は歩 行して近くの芽に到達することがわかった（第 2 図の 5 ）。その後，この幼虫は幹母となり，その子孫は 5 月 初めまで世代をくりかえして，5 月中旬に本植物体上に はじめて有翅虫が出現した。有翅虫は次第に增加し, 次 々に飛散するが，有翅虫のもっとも多くなるのは 6 月初 めである。6月末には一時本植物上の個体数は少なくな るが, 夏から秋にかけで常に無翅出, 有翅虫とも見られ る。

6 月初めジャガイモへの接種を行なったところ, 羽化 後数時間, 24 , 18時間のものはいずれも幼虫を産季ない で，大部分の個体は接種後まもなくがラス鐘内を飛びま わったり，その壁面にとどまってさかんに歩きまわっ た。24時間後には全個休がジャガイモ葉上を離れて，48 時間後には姿を諗めなくなった。羽化後70時間絶食状態 においたものは10頭のうち7頭はジャガイモの葉上を離 れて死亡したが, 残った 3 頭はジャガイモの葉裏に幼虫 を産久, 約 6 日後には暗緑〜濃緑色の成虫になった。こ の結果から,ナカネにいる個体はジャバイモにはややっ きにくいように思われる。野外のジャガイモに奇生して いるワタアブラムシの中には，アカネからジャガイモへ の接種試験の結果, 成育したような色彩・形態の個体が 多くはないが見られるので, 自然状態でも本植物からジ ヤガイモへ有翅虫が飛来し, 笴生するものと思われる。 なお, 本植物に咨生するフブラムシについては, 宗林正 人博士の同定を受けた。

\section{e) ツルウメモドキ}

ツルウメモドキ Celastrus orbiculatus THUNB. は曼性 の多年性木本で, 畑地の周辺や林縁, 水田を流れる小川 の縁, 河原の堤などに普通に見られる。従来, 本植物は 進士 (1941), 森津 (1948) によってワタアブラムシの寄 主植物として報告されていたが，卵越冬する主等主植物 としては，まったく知られていなかった。

筆者は1967年 5 月初め, 静岡県清水市および宇都宮市 に执いて本植物上に多数の有翅虫を発見し，主寄主では ないかと考えていた。同年11月初め, 宇都宮市に扎い て, 本植物上飞産畉中の産卵雌虫を, また，1968年 4 月 初めには卵の卯化を確認した。卵は曼の先端に近い芽の 付近に多い（第 2 図の 2)。本植物はいたるところに見 られるが，卵の見つかる木の本数はあまり多くない。し かし，春になってからの本植物上での幹母の子孫, 春季 移住する有翅虫の数は相当多数にのぼる。

ジャガイモへの接種試験の結果は, 大体アカネの結果 に近く, 羽化後の絶食時間が24，48時間までのものは幼
虫を産おず，70時間で少数の個体が幼虫を産んだ。その 後数世:代の飼育を行なったところ，暗縁色〜暗青縁色の 個体になった。このような個体は野外のジャガイモにか なり笴生している。

\section{f) クロウメモドキ}

クロウメモドキ Rhamnus japonica MAxim. は多年性 の木本で, 水田間小川の縁や河原などに自生してい る。これまでワタアブラムシの寄主植物としてはまった く知られていなかった。

筆者は1966年 5 月中旬, 杤木県那須町に拈いて本植物 上に多数の春季移住する有翅虫を見つけた。1968年11月 初めには宇都宮において本植物上に卵と産畉雌虫を発見 乙(第 3 図の 1，2)，1969年 4 月初めに卵の餒化，5月

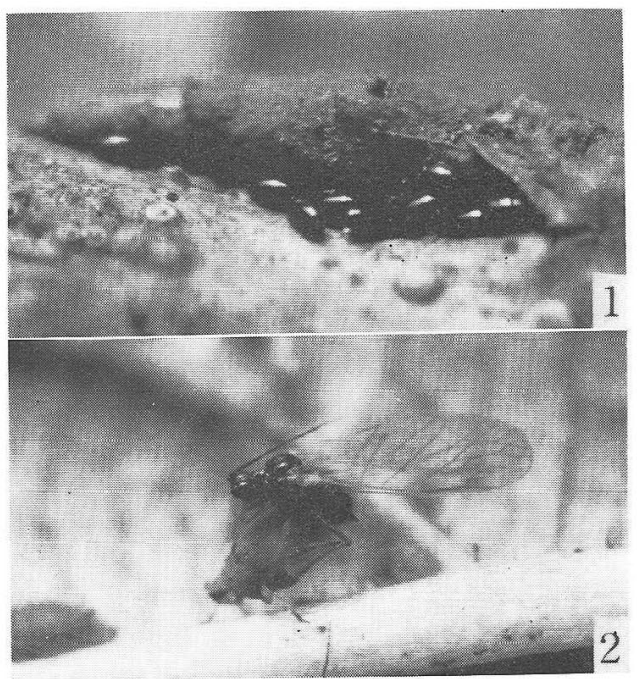

第 3 図 主奇主上のワタアブラムシ(2)。1.クロウ メモドキの芽の付近に産つつけられた卵（長さ $0.4 \mathrm{~mm}$ )。 2.クロウメモドキの葉亭で交尾中の産卵雌虫（体長 1.2 $\mathrm{mm}$ ) と雄 (有题)。

初めに有翅虫の羽化を確認した。

ジャガイモへの接種試験の結果は,アカネ, アルウメ モドキとほとんど同様で,ややつきにくいことがわかっ た。

\section{2. 胎生雌越冬寄主植物}

ワタアブラムシの越冬については，前述のよらに諸外 国では卵越冬するところと，卵越冬しないところとがあ る。卵越冬しないところでは，执そらく胎生雌越冬する か，あるいは一年中高温が続くため越冬ということがな く, 常に胎生世代をくりかえしているものと思われる がこれらのことを明記した報告は見あたらない。した がって, 諸外国での胎生雌越冬奇主植物についてはよく 
わかっていないようである。わが国での本種の胎生雌越 冬についても従来はっきりした報告はないようである。 ただ，田中（1963）が本種の越冬時より春さきの寄主植 物として，タチアオイ，イヌノフグリ，キクなどをあげ たものが見られるだけである。筆者は，わが国の本種の 胎生雌越冬と, その寄主植物について, いくつかの知見 を得たので報告する。

\section{a) イヌノフグリ類}

イヌノフグリ類（オオイヌノフグリVeronica persica PoIr, イヌノフグリV. didyma Tenore var. lilacina YAMAZAKI, タチイヌノフグリ $V$. arvensis L.) は, い たるところの道端や畑に普通に見られる 2 年性の雑草で ある。古くから本虫の寄主植物として知られていたが, 本植物類でワタアブラムシが胎生雌越冬することははっ きりしていなかった。

本植物上では冬季間, 葉や芽の基部にもぐって越冬し ている。1，2月にも幼虫, 成虫が見られるので, 冬季 でもわずかに世代をくりかえしているものと思われる。 3 月頃から急に個体数が増えはじめ，4 月20日前後に有 翅虫が出現し, さかんに飛び立っていく。その後, 夏, 秋とも本植物上に寄生している。

ジャガイモへの接種では，羽化間もない有翅虫でも， 無翅虫でもよく幼虫を産み, 継続して数世代の飼育を行 ならことができた。本植物体は小さく，1 本の植物体あ たりの本虫の越冬個体数や春の有翅虫の発生数は少ない が，野外に打䧺植物の数量は非常に多く，もっとも 有力な本虫の発生源となりらる。

野外において本植物に寄生している本虫の体色は, 越 冬時には灰青色，灭緑褐色をしているが，5〜6月にな ると, 次第にうす緑色, 黄緑, 黄褐色, 黄色となり, 夏 には黄色のものが多い。室内においてガラス張りの定温 器を用い, $12,20,25^{\circ} \mathrm{G}$ で 3 世代まで飼育を行なって みると, $12^{\circ} \mathrm{C}$ では濃青, 暗褐, $20^{\circ} \mathrm{C}$ ではうす緑褐, らす緑, $25^{\circ} \mathrm{C}$ では黄褐色, 黄色となった。このことから みると，高温になるに従って，体色はうすい黄色になる ことがわかる。宇都宮市の日平均気温にあてはめると, $12^{\circ} \mathrm{C}$ は 4 月中旬, $20^{\circ} \mathrm{C}$ は 6 月下旬, $25^{\circ} \mathrm{C}$ は 8 月中旬 にあたり，野外の状態と実験の結果は大体一致するよう である。

\section{b) タチアオイ}

タチアオイ Althaea rosea CAv. は花を観賞する目的 で人家の庭さきなどに普通に見られる越年性の草本であ る。

本植物は冬季になると地面近くに数枚の葉を残して越
年しているが，この葉裏や葉の基部などに少数の胎生雌 虫が越冬する。3 月頃になって, 植物体が生育をはじめ ると, 本虫子急に増加し, 例年 4 月 25 日前後に有翅虫が 出現し，5月初めには有翅虫の数はおびただしい数にの ぼる。その後も夏から秋にかけて年中寄生しているのが 見られる。

ジャガイモへの接種では, 羽化後数時間の個体が接種 後24時間以内に幼虫を産及, $5 \sim 6$ 日後には黄〜うす黄 緑，らす緑色の成虫になった。このような個体は野外の ジャガイモに多数奇生している。

\section{c) キク}

キク Chrysanthemum morifolium RAMAT. var. sinense MAKINO 女古くから本虫の中間寄主植物として知られて いた。本植物は宇都宮付近では冬季になると地上部はほ とんど枯死してしまらが，一部の品種ではわずかに緑色 の葉を残している。本虫は地面に接した葉の裏や芽の付 近などに胎生雌のまま少数の個体が越冬している。4 月 20 日前後には有翅虫が出現し飛び立っていくが, 同植物 体上でも夏から秋にかけて胎生繁殖をくりかえす。本植 物体に寄生する個体は, 春, 秋, 冬の間は大部分濃青緑 巴をしているが，夏の間は黄〜黄緑色をしている。

ジャガイモへの接種を行なったところ, 羽化数時間の 個体は，接種後24時間以内に死亡または逃亡したが, 羽 化後24〜48時間絶食状態で保ったものは少数の幼虫を産 み，その後数世代の飼育を行ならことができた。また， 8 月に本植物より採集した黄色の無翅虫をジャガイモへ 接種したところ,よく幼虫を産み, 数世代の飼育を行な らことができた。

\section{d) イチゴ}

イチゴ Fragaria chiloensis Duch. var. ananassa BAILEY 女従来ワタアブラムシの中間奇主植物としては知ら れていたが，胎生雌越冬寄主としては知られていなかっ た。

本植物では，冬期には地面に接した葉裏や，地ぎわの 芽の付近に少数の無翅虫が見られる。3 月頃から植物体 の生育につれて本虫の個体数も増え, 4 月中, 下旬に有 翅虫が出現し飛散するが，一部は同植物体で一年を通じ て胎生世代をくりか方す。゙ニールを用いたハウス，卜 ンネル栽培の場合には，2 月頃から地ぎわの芽の付近に 多数堌殖しており，3 月頃には有翅虫も見られる。

ジャガイモへの接種では, 羽化後数時間, 24時間では 幼虫を産まず，48時間以上絶食で経過した個体は少数の 幼虫を産み，数世代の飼育を行ならことがでさた。

e ) ナズナ 


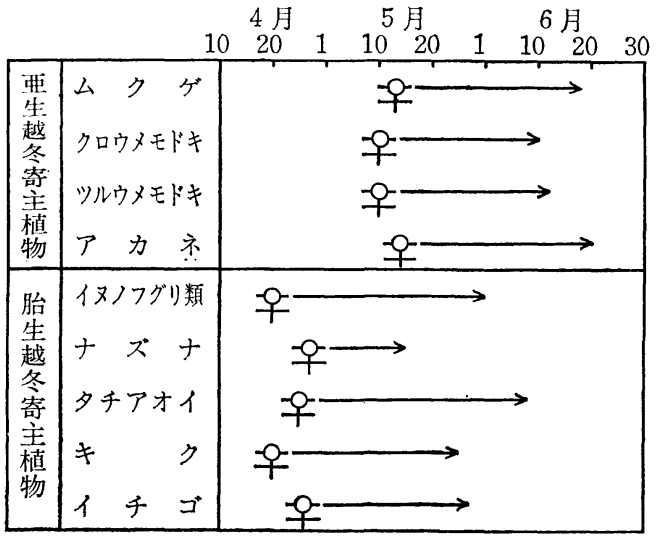

第 4 図 越冬寄主植物上における有翅虫の羽化期 （尔は有翅虫を， （は有翅虫の見られる期間を示す）。

ナズナ Capsella bursa-pastoris MEDICUs は道端や畑 地, 水田などにもっとも普通に見られる越年性雑草であ る。従来, 本植物は TheOBALd (1927), PATCH (1938), Palmer (1952), CotTier (1953) らによって本虫の奇主 植物となることが報告されていた。わが国では森津 (1948) がナズナの 1 種から記録している。しかし，本 植物が本虫の胎生雌越冬寄主となりらることは未知であ った。

本虫は冬季, 本植物の芽の付近に胎生雌のまま越冬す る。 3 月頃になって花梗が長くのびてくると, その先端 付近に多数増殖する。4 月末には有翅虫が出現し, さか んに飛び立っていく。田植前の乾燥した水田には本植物 が一面に繁茂し, 多数の本虫の寄生がみられ, 植物体の 枯死する 5 月中旬まで有翅虫の羽化が続く。

ジャガイモへの接種では, 羽化後 24 時間以上絶食状態 で経過した個体がよく幼虫を産み, その後数世代の飼育 を行ならことができた。

本植物の畑地付近の量, 本植物体上で羽化する有翅虫 の数量からみて, イヌノフグリ類に次いで有力な本虫の 越冬源と考えられる。

\section{f）その他}

ジャガイモへの接種を行なっていないが，笴生してい る胎生雌虫の形態から, 本虫の胎生雌越冬寄主植物とし てあげられるものに, ヒリハリソウ Symphytum officinale L., オオバコ Plantago asiatica L. などがある。

越冬寄主植物上にはじめて有翅虫の羽化する時期, お よびその見られる期間をまとめて示すと第 4 図のように なる。

\section{II. 中間寄主植物上に有翅虫の飛来する時期}

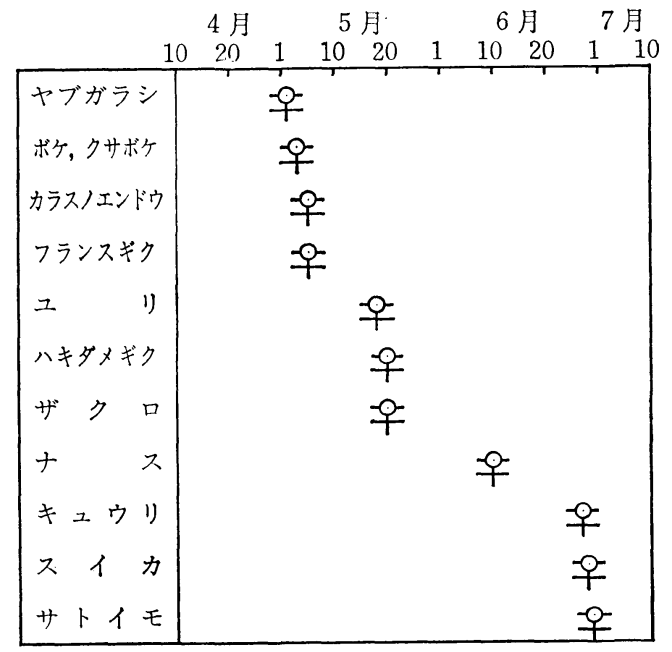

第 5 図 中間寄主植物にワタアブラムシ有翅虫の飛 来する時期（架は有翅虫を示す）。

野外においてワタアブラムシの越冬寄主植物以外の中 間寄主植物上に, はじめて有翅虫の飛来する時期を知る ため, 早春多数の植物の観察を行なった。

その結果のらちおもなものをあげると第 5 図のように なる。すなわち, 越冬寄主からはじめて有翅虫の飛来を 受けるおもな植物はヤブガラシ, ジャガイモ, フランス ギク, ザクロ, ボケ, クサボケ, カラスノェンドウなど で，その時期は 5 月上旬である。これらの植物体上に飛 来した有翅虫は数日間に数頭〜数 10 頭の幼虫を産む。そ の後, 世代をくりかえして増加し, 約20日間は有翅虫の 出現は見られないが，次第にこれらの植物上にも有翅虫 が出現し, 次の奇主へと移っていく。

雑草類の中でもっとも春早く有翅虫の飛来を受けるの はヤブガラシである。ヤブガラシは, イスノフグリ類や ナズナなどの生えているところに混生している多年性の

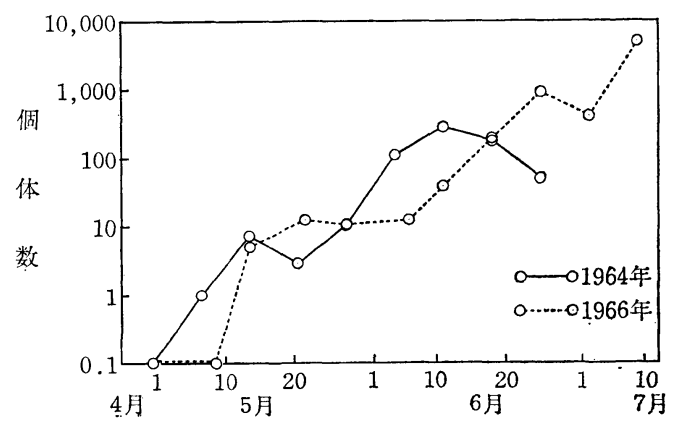

第 6 図 ジャイモ上に扑けるワタアブラムシ有翅虫 の個体数（縦軸は茎または株あたり平均個体数 $+0.1 ） 。$ 
蔓植物であるが，植物体が地上に芽を出し，若い葉が展 開する 5 月初めに有翅虫の飛来をうける。その後, 葉裏 に打びただしく増殖し，5月20日頃には葉裏一面有翅虫 でお拈われる。夏から秋にかけても多く寄生しており， 重要な第二次発生源となる。

農作物のらちで, 春もっとも早く本種の有翅虫の飛来 と寄生をらけるのはジャガイモであるが，ジャガイモ上 飞有翅虫の飛来する時期を調查してみると, 第 6 図のよ らになる。調査の方法などは稲泉（1968）による。この 結果から，ジャガイモにはじめて有翅虫の飛来するのは 5 月10日前後で, その後約 1 か月間飛来が継続すること がわかる。また， 6 月上旬からジャガイモ上の有翅虫の 個体数が增加しているが，これは，この頃からジャガイ モ上に有翅虫の幼虫拉よび成虫が発生したことを示して いる。

\section{考察}

ジャガイモに寄生するワタアブラムシが春どこからや ってくるかについては，まだよくわかっていなかった。 そこで，まずワタアブラムシの越冬寄主植物は何かにつ いて調查したところ，卵越冬する植物はムクゲ，ツルウ メモドキ,クロウメモドキ, アカネ, 胎生雌越冬する植 物はイヌノフグリ類, キク，タチアオイ，ナズナ，イチ ゴなどであることがわかった。次に，それらに春生まれ た有翅虫をジャガイモに移した場合，幼虫を産み，さら に繁殖をくりかえすことができるかどらかについて調査 したところ，いずれの植物の有翅虫もとれが可能である ことがわかったが，その中には，つきやすいものと，つ きにくいもののあることがわかった。すなわち，ムク ゲ,イヌノフグリ類, タチアオイ,ナズナではつきやす く、アカネ, ツルウメモドキ，クロウメモドキ，キク， イチゴではつきにくい。この理由については不明で，今 後検討を要するが，ワタアブラムシの中にもいくつかの 生態型があって，それぞれに好みの寄主植物があるため とも考光られる。

野外に掠いてジャガイモに寄生しているワタアブラム シ無翅虫の体色をみると，種々なものがあるが，類別す ると大体次のようになる。A．黄色，B．うす黄緑色， G. 万す緑色，D，濃青緑色， E．濃青緑褐色， F，緑 褐色。一方, 各越冬寄主植物より有翅虫をジャガイモに 移し，そこで生育した無翅虫の体色をみると、ムクゲか らのものはA，以下，アカネ，クロウメモドキ,ツルウ メモドキでは $\mathrm{C}, \mathrm{D}$, ナズナ, イヌノフグリ類では $\mathrm{A}$, $\mathrm{C}, \mathrm{D}, \mathrm{E}, \mathrm{F}$, タチアオイでは $\mathrm{A}, \mathrm{B}, \mathrm{C}$, キク, イ
チゴではB， C，Dになった。体色からでは，いずれも ジャガイモに寄生する可能性がある。

また，ジャガイモ葉上にはじめて有翅虫の飛来するの は 5 月10日前後であったが，第 4 図化も示す通り，越冬 寄主植物に有翅虫の発生する時期を見ると, 胎生雌越冬 寄主では 4 月 20 日〜 4 月末，卵越冬寄主では 5 月10日前 後になっている。ジャガイモに有翅虫が飛来するには， 越冬寄主植物上での有翅虫の発生が相当数にのぼり, 空 中での個体数の密度がある程度増加しなければならない ので, 越冬寄主植物に有翅虫が発生してからジャガイモ などの中間寄主植物に飛来降下するまでには数日間を要 するものと考えられる。このことから，5月10日前後に はじめてジャガイモに飛来した有翅虫は胎生雌越冬した イヌノフグリ類, ナズナ, タチアオイ, キクなどが発生 源となっているものと考光られる。しかし, ジャガイモ への有翅虫の飛来は 5 月10日頃から約 1 か月は続くの で，次第にほかの卵越冬した植物からも飛来する可能性 がある。

また，固場付近の越冬植物の量，および越冬寄主植物 上澄生する有翅虫の個体数についても考光なければな らないが，越冬植物の量の多いものからあげると，イヌ ノフグリ類, ナズナ、ッルウメモドキ，アカネ，ムク ゲ, タチアオイ, キク，イチゴおよびクロウメモドキの 順になる。有翅虫の発生量の多いものからあげると, イ ヌノフグリ類, ナズナ，ムクゲ，クロウメモドキ，タチ アオイ、アカネ, ッルウメモドキ,イチゴおよびキクの 順である。

以上の諸点から考えて，ジャガイモに寄生するワタフ ブラムシの発生源としてもっとも有力なのは, イヌノフ グリ類,ナズナ、ムクゲなどであると推察される。

ジャガイモのほかに，早春ワタアブラムシ有翅虫の飛 来をうける植物としては第 5 図に示すようにカラスノェ ンドゥ, ボケ, クサボケ, ザクロ, ヤブガラシ, ユリ, フランスギク，八キダメギクなどがある。これらで増殖

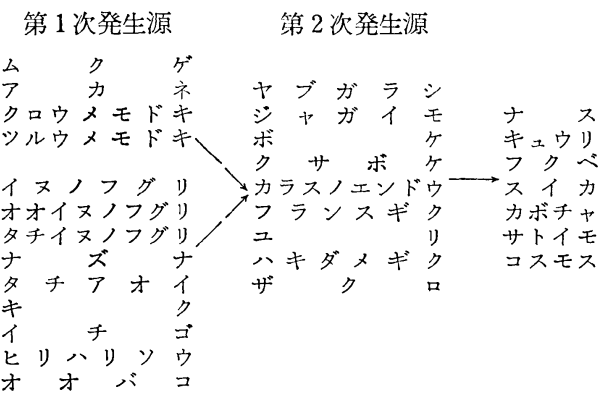

第7図 ワタアブラムシの春から夏にかけての伝播経路。 
第 1 表 世界各地のワタアブラムシの越冬法と気温

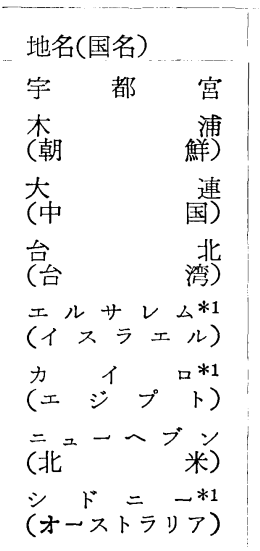

\begin{tabular}{|c|c|c|c|c|c|}
\hline $\begin{array}{c}\text { 11月の平均気温 } \\
\left({ }^{\circ} \mathrm{C}\right)\end{array}$ & 越冬法(越冬寄主植物) & 引 & 用 & 文 & 献 \\
\hline 8.8 & 卵生および胎生 & & & & \\
\hline 10.3 & $\begin{array}{c}\text { 畉生(ザクロ, ムクゲ, } \\
\text { フョウ) }\end{array}$ & 江口 (1937) & & & \\
\hline 5.3 & $\begin{array}{c}\text { 卵生(ムクゲ, クサギ, } \\
\text { オオバコ) }\end{array}$ & 柴田 (1955) & & & \\
\hline 20.5 & 胎生 & TAKAHASH & I $(19$ & & \\
\hline
\end{tabular}

BODENHEIMER and Swirsky

15. $3^{* 2}$

胎生

19.7

胎生

同上

8. $6 * 3$

卵生(アメリカキササゲ,

KRING (1959)

13. $0 * 4$ 胎生

(1957)

EASTOP (1966)

*1 文献の中に国名しかあげてないので，その国の代表的な都市の気温をあげた。＊2 ェルサレムの気 温は不詳のため約同緯度で, もっとも近いアンマン（ヨルダン）の気温をあてはめた。 *3 同様に二= ーヨークの気温をあてはめた。 *4 オーストラリアの11月は初夏にあたるので, 日本の11月に見合5 6 月の気温をあげた。（注）気温は理科年表（1965）による。国名は文献のと和りとした。

した有翅虫は第二次発生源となって，さらにキュウリ， カボチャ,スイカ, ウリ，フクベ，ナス，サトイモなど へ飛来するものと考えられる。ワタアブラムシの春から 夏にかけての伝播の経路をまとめると, 第 7 図のように なる。したがって, 第一次発生源となる越冬寄主植物の 畑地周辺からの除去, および雑草類の防除が本虫の防除 上非常に重要である。

本文中で述べたワタアブラムシの越冬法，および越冬 奇主植物は宇都宮市周辺での調査の絬果である。宇都宮 市付近の本虫は卵, および胎生雌の 2 越冬法をとるが, 緯度 (気温差) によって越冬法は違らことが予想され る。すなわち, 寒帯では卵越冬の久, 熱帯では胎生雌の み, 温帯では卵および胎生雌越冬するものと思われる。 これまで本虫の越冬法の報告がある地名と, 11月の平均 気温, 越冬法を示すと第 1 表のようになる。11月の気温 をあげた理由は，この頃宇都宮市に㧅ててロタアブラ ムシの産卵が行なわれるためである。越冬法の相違は気 温だけによるのか，また，気温が第一義的だとした場合 には最低気温か，あるいは温度格差なのかなどの点につ いては不明であるが，11月の平均気温に限ってみると， 卵越冬するところでもっとも気温の高いのは木浦（朝 鮮) の $10.3^{\circ} \mathrm{C}$, 胎生雌越冬するところでもっとも低い ところがェルサレム (イスラェル) の $15.3^{\circ} \mathrm{C}$ である。 このことから卵越冬するのは $12 \sim 13^{\circ} \mathrm{C}$ 以下の地域とい ら予想ができる。また, 胎生雌越冬については, $8.8^{\circ} \mathrm{C}$ の宇都宮でも可能な点からみて, 卵越冬のみを行なら大
連（中国）の5. $3^{\circ} \mathrm{G}$ との間，つまり $7^{\circ} \mathrm{G}$ 前後以上という 予想ができる。したがって，これらの予想から， $7^{\circ} \mathrm{CW}$ 下では卵越冬のみ, $7 \sim 12,3^{\circ} \mathrm{C}$ では卵および胎生雌越 冬, $14^{\circ} \mathrm{C}$ 以上では胎生雌越冬のみを行ならのではない かと推察される。わが国の場合をみると，まだ，どこで ぞういう越冬法をとるかについての報告はないが，上述 の推察からすれば, 札幌 $\left(3.6^{\circ} \mathrm{C}\right)$, 青森 $\left(6^{\circ} \mathrm{C}\right)$ では, 㧈そらく卵越冬のみ, 山形 $\left(6.7^{\circ} \mathrm{C}\right)$ では卵のみか, あるいは胎生雌による越冬も行ならかの境, 福島 (8.3 $\left.{ }^{\circ} \mathrm{G}\right)$, 東京 $\left(11.3^{\circ} \mathrm{G}\right)$ では卵持よび胎生雌, 高知(12.9 $\left.{ }^{\circ} \mathrm{G}\right)$, 鹿児島 $\left(14^{\circ} \mathrm{C}\right)$ では両方か, あるいは胎生䧳の み, 名瀬 $\left(19.8^{\circ} \mathrm{C}\right)$ では胎生雌のみといら予想がたて られるであろう。以上, 11月の平均気温で越冬法の推察 を試みたが，そのほかに積雪や植物体の越冬状況なども 関係すると思われるので, 今後実際に調査してみたいと 思う。

\section{摘 要}

従来, わが国のワタアブラムシは卵態でクサギ，ムラ サキシキブ，ムクゲに越冬することが知られていたが， 筆者は胎生雌越冬も寸ることを確かめた。また，クサ ギ,ムラサキシキブに卵を産むアブラムシはワタアブラ ムシとは異なる，泳の Aphis の1種であることをつ きとめた。

さらに, 卵越冬する植物として, アカネ, ツルウメモ ドキ,クロウメモドキを, 胎生雌越冬する植物として, 
オオイヌノフグリ, タチイヌノグリ，イヌノフグリ，ナ ズナ, タチアオイ, キク, イチゴ, オオバコなどを記載 した。

また，野外について，これらの冬寄主上に春はじめて 有翅虫の羽化する時期と, 中間寄主へはじめて有翅虫の 飛来する時期とを調查し, その結果からワタアブラムシ の冬から夏にかけての伝播の経路を推察した。

そのほか, 世界各地のワタアブラムシの越冬法につい ての知見をもとにして, 卵および胎生雌越冬と気候, 地 理との関係を論じた。

\section{引用文 献}

Bodenheimer, F. S. and E. Swirski (1957) The aphidoidea of the Middle East. Weizmann Science Press. Jerusalem, 294 297 .

Börner, C. and K. Heinze (1957) In Sorauer, P. Handb. Pfkrankh. 5th Ed. 129 132.

Cottier, W. (1953) Aphids of New Zealand. Bull. N. Z. Dep. Scient, Ind. Res. 106: 191 195.

EAstop, V. F. (1958) A study of the Aphididae (Homoptera) of East Africa. Her Majesty's Stationery Office. London, 72 73 .

EAstop, V. F. (1966) A taxonomic study of Australian Aphidoidea (Homoptera). Aust. J. Zool. 14: 481.

江口 貢 (1937) ワタアブラムシに関する試験調査ならびに防
除応用試験成績. 朝鮮総督府農事試験場菓報 9: 1 415, 稲泉三丸 (1968) ジャガイモに寄生するアブラムシ類の発生消 長に影響する諸要因について。応動昆 12：10〜17.

KRING. J. B. (1959) The life cycle of the melon aphid, Aphis gossypii Glover, an example of facultative migration. Ann. Ent. Soc. Amer. 52: 284 286.

森津孫四郎 (1948) わが国に於ける有害䖣虫（1)ジャガイモの 蚵虫. むし 18: 67〜75.

Palmer, M. A. (1952) Aphids of the Rocky mountain region. Thomas Say Foundation. Denver, 139 140.

PATch, E. M. (1938) Food-plant catalogue of the aphids of the world. Bull. Me. Agric. Expt. Sta. 393: 1 431.

柴田文平 (1955) 蚜虫の生態的研究(9) 生態について. 宇都宮 大学農学部学術報告 $3(1) ： 1 \sim 8$.

進士織平 (1941) 日本䖣虫総説, 修教社, 東京, 1201 1215.

TAканаShi, R. (1932) Aphididae of Formosa. -2- Dep. Agr. Gov. Res. Ins. Formosa, Japan. 4: 97 99.

TаканаShi, R. (1966) Descriptions of some new and little known species of Aphis of Japan, with key to species. Trans. Amer. Ent. Soc. 92: 519 556.

田中 正 (1963) アブラムシの発生予察法の一案. 応動昆 7: $277 \sim 278$.

Theobald, F. V. (1927) The plant lice or Aphididae of Great Britain. Headley Brothers, London II: 141 145.
時

\section{第3回国際植物保護会議}

第 3 回国際植物保護会議 (III C Congrès International des Antiparasitaires) は1969年10月6日より8日の3 日間にわた って,イタリヤ国のミラノ市のレオナルド・ダ・ビィンチ記念 工業博物館に怙いて開催された。25か国より 264 名の参加者が めってかなり盛大な会議であった。わが国からは日本学術会議 代表として湯鳴健が出席したほか, 名大宗像桂氏の誌上参加が あった。発表論文数は総説 6 編，一般講演はプレプリント無し
報

の講演もかなりあって約60題の発表があった。

講演公用語は英・独・仏・伊の 4 か国語で，イヤホーンによ る同時通訳が行なわれた。プレプリントは全公用語によるしっ かりした要訳があった。同時通訳はかなり難解で，座長をつと めた人によるリコメンデーションの中でもこの点をかなりきび しく指摘された。

出席者の大部分はヨーロッパ諸国からであったが，今後もっ と他の地域からの参加者のあるよう呼びかけが決議されだ。

（農技研 湯鳰 健） 